University of Nebraska - Lincoln

DigitalCommons@University of Nebraska - Lincoln

2009

\title{
Evaluation of antral follicle count and ovarian morphology in crossbred beef cows: Investigation of influence of stage of the estrous cycle, age, and birth weight
}

\author{
R. A. Cushman \\ USDA-ARS, Bob.Cushman@ars.usda.gov \\ M. F. Allan \\ USDA-ARS \\ Larry A. Kuehn \\ USMARC, Larry.Kuehn@ars.usda.gov \\ W. M. Snelling \\ USDA-ARS, warren.snelling@ars.usda.gov \\ Andrea S. Cupp \\ University of Nebraska-Lincoln, acupp2@unl.edu \\ See next page for additional authors \\ Follow this and additional works at: https://digitalcommons.unl.edu/animalscifacpub \\ Part of the Animal Sciences Commons
}

Cushman, R. A.; Allan, M. F.; Kuehn, Larry A.; Snelling, W. M.; Cupp, Andrea S.; and Freetly, H. C., "Evaluation of antral follicle count and ovarian morphology in crossbred beef cows: Investigation of influence of stage of the estrous cycle, age, and birth weight" (2009). Faculty Papers and Publications in Animal Science.

704.

https://digitalcommons.unl.edu/animalscifacpub/704

This Article is brought to you for free and open access by the Animal Science Department at DigitalCommons@University of Nebraska - Lincoln. It has been accepted for inclusion in Faculty Papers and Publications in Animal Science by an authorized administrator of DigitalCommons@University of Nebraska - Lincoln. 


\section{Authors}

R. A. Cushman, M. F. Allan, Larry A. Kuehn, W. M. Snelling, Andrea S. Cupp, and H. C. Freetly 


\title{
Evaluation of antral follicle count and ovarian morphology in crossbred beef cows: Investigation of influence of stage of the estrous cycle, age, and birth weight ${ }^{1,2}$
}

\author{
R. A. Cushman, ${ }^{* 3}$ M. F. Allan, ${ }^{*}$ L. A. Kuehn, ${ }^{*}$ W. M. Snelling, ${ }^{*}$ A. S. Cupp, $\dagger$ \\ and H. C. Freetly*
}

*USDA, ARS, Roman L. Hruska US Meat Animal Research Center (USMARC), PO Box 166, Clay Center, NE 68933; and †Department of Animal Science, University of Nebraska, Lincoln 68583-0908

\begin{abstract}
Depletion of the ovarian reserve is associated with reproductive senescence in mammalian females, and there is a positive relationship between the size of the ovarian reserve and the number of antral follicles on the surface of the ovary. Therefore, we conducted a series of experiments to investigate the influence of stage of the estrous cycle, age, and birth weight on antral follicle counts (AFC) in beef cows and heifers. Pairs of ovaries were collected from crossbred beef cows at slaughter $(\mathrm{n}=72)$ or at necropsy $(\mathrm{n}=333 ; 0$ to 11 yr of age); all visible antral follicles were counted, the ovaries were weighed, and stage of the estrous cycle was estimated based on ovarian morphology. There was no influence of estimated stage of the estrous cycle on AFC $(P=0.36)$. There was a small but positive effect of birth weight on AFC $[\mathrm{AFC}=-1.7+0.31$ (birth weight); $\left.P=0.007, \mathrm{r}^{2}=0.05\right]$. When antral follicle counts were regressed on age, there was a quadratic effect of age such that AFC increased until $5 \mathrm{yr}$ of
\end{abstract}

age and decreased thereafter $[\mathrm{AFC}=12.9+9.0(\mathrm{yr})-$ $\left.0.86\left(\mathrm{yr}^{2}\right) ; P<0.001, \mathrm{r}^{2}=0.22\right]$. In a third experiment, crossbred beef heifers $(\mathrm{n}=406 ; 353$ to $463 \mathrm{~d}$ of age $)$ at 3 locations were subjected to ovarian ultrasonography on unknown day of the estrous cycle. Heifers were classified as low AFC ( $<15$ follicle, $\mathrm{n}=84)$ or high AFC $(>24$ follicles, $n=178)$. Whereas estimated stage of the estrous cycle did not influence $\operatorname{AFC}(P=0.62)$, heifers classified as low AFC had smaller ovaries $(P=0.001)$, decreased birth weight $(P=0.003)$, and a decreased heifer pregnancy rate $(P=0.05)$ compared with heifers in the high AFC group. From these results, we conclude that AFC in beef cows and heifers is influenced by birth weight and age but not by stage of the estrous cycle. In beef cows, the number of antral follicles increases to 5 yr of age and then begins to decline. This may indicate that a decrease in fertility due to decline of the ovarian reserve may begin earlier than previously thought in beef cows.

Key words: age, antral follicle count, beef cow, birth weight, fertility

(C)2009 American Society of Animal Science. All rights reserved.

This article is a U.S. government work, and is not subject to copyright in the United States.
J. Anim. Sci. 2009. 87:1971-1980 doi:10.2527/jas.2008-1728

\section{INTRODUCTION}

Cow longevity is a primary factor affecting profitabil-

${ }^{1}$ Names are necessary to report factually on available data; however, the USDA neither guarantees nor warrants the standard of the product, and the use of names by the USDA implies no approval of the product to the exclusion of others that may also be suitable.

${ }^{2}$ The authors gratefully acknowledge G. Hays (USMARC, Clay Center, NE), M. Wilford (USMARC), K. Moline (University of Nebraska, Lincoln), J. Bergman (University of Nebraska, Lincoln), and USMARC Cattle Operations for care of the animals and data collection; the Great Plains Veterinary Educational Center for collection of ovaries; K. Beavers (USMARC) and M. Messersmith (USMARC) for expert assistance in the laboratory; L. Parnell (USMARC) for manuscript preparation; and D. Light (USMARC), L. Eckhardt (USMARC), and L. Larsen (USMARC) for data management.

${ }^{3}$ Corresponding author: Bob.Cushman@ars.usda.gov

Received December 12, 2008.

Accepted February 16, 2009. ity for cow-calf producers (Renquist et al., 2006), and failure to become pregnant is the primary reason that a beef cow is removed from the production herd. Reproductive aging results in decreased pregnancy rates with increasing parity in cows (Erickson et al., 1976; Martinez et al., 2004a,b, 2005). In part, this may be due to depletion in the number of follicles in the ovary (the ovarian reserve) because depletion of the ovarian reserve is associated with menopause in women (Broekmans et al., 2007) and repeat-breeder cows have fewer antral follicles in their ovarian cortex (Maurer and Echternkamp, 1985). Variation in the size of the ovarian reserve also may be influenced by birth weight; ewe lambs nutritionally induced to have reduced birth weight have 
smaller ovaries and smaller ovarian reserves (Da Silva et al., 2002, 2003).

One method for assessing the ovarian reserve in a production setting is to assess the population of antral follicles by ultrasonography. For antral follicle count (AFC) by ultrasonography to have application as an indicator trait of fertility and reproductive longevity in the beef industry, it will need to be a viable measurement at random stages of the estrous cycle. Alvarez et al. (2000) reported breed differences in AFC by ultrasonography with no influence of day of the estrous cycle on the number of small follicles detectable by ultrasonography. Burns et al. (2005) reported a high repeatability of peak AFC within cows with a large variability between cows in the number of antral follicles detectable by ultrasonography. Based on these data, it seems that a random stage of the estrous cycle may be acceptable in assessing AFC. The objective of the present study was to determine the relationship between stage of the estrous cycle, age, birth weight, and variation in AFC in beef heifers and cows using ultrasonography and ovarian morphological evaluation.

\section{MATERIALS AND METHODS}

This research was conducted in accordance with procedures approved by the Institutional Animal Care and Use Committee at the US Meat Animal Research Center (USMARC) and the University of NebraskaLincoln.

\section{Exp. 1}

Pairs of ovaries $(\mathrm{n}=72)$ were collected from cyclic [corpus lutea (CL) present], nonpregnant bovine reproductive tracts at a local abattoir and transported to the laboratory. No attempt was made to estimate the age of the animals from which the reproductive tracts were collected. At the laboratory, extra tissue was trimmed away from the ovaries, and the CL were removed from the ovaries. Ovaries were weighed, all visible surface follicles were counted, and individual follicles $>5 \mathrm{~mm}$ were measured and classified as medium (6 to $10 \mathrm{~mm}$ ) and large $(>10 \mathrm{~mm})$. Morphology of the CL and follicle populations were assessed according to the methods of Ireland et al. $(1979,1980)$ to estimate stage of the estrous cycle. Briefly, the stage of the estrous cycle was classified as stage 1: a recently ovulated follicle (d 1 to 4); stage 2: early luteal development with medium or large or both present (d 5 to 11); stage 3: fully functional CL yellow or orange in color (d 11 to 17); or stage 4: regressing CL with little vasculature and a large preovulatory follicle present (d 18 to 20). A second classification was performed where only progression of the follicular wave was assessed. Progression of the wave was defined as early-wave: only small $(\leq 5$ $\mathrm{mm}$ ) follicles present; mid-wave: medium (6 to $10 \mathrm{~mm}$ ) follicles present; or late-wave: large $(>10 \mathrm{~mm})$ follicles present. Additionally, pairs of ovaries were classified by
AFC according to the methods of Ireland et al. (2008). Ovarian pairs with $<16$ antral follicles were classified as low AFC; ovarian pairs with 16 to 24 antral follicles were classified as intermediate AFC; and ovarian pairs with $>24$ antral follicles were classified as high AFC.

\section{Exp. 2}

Pairs of bovine ovaries ( $\mathrm{n}=333$ pairs $)$ were collected from crossbred beef cows (ages 0 to 11 yr of age) at necropsy and transported to the laboratory for further phenotypic evaluation. Ovaries were collected from neonatal calves ( $\mathrm{n}=181$ pairs) that died due to dystocia and from mature cows $(\mathrm{n}=152$ pairs $)$ that died from natural causes. Animals demonstrating severe or long-term illnesses were excluded from the data set. Extra tissue was trimmed away from the ovaries, and the corpora lutea were removed from the ovaries. All visible surface follicles were counted, and the ovaries were weighed. As in Exp. 1, stage of the estrous cycle was assessed for mature cows according to the method of Ireland et al. $(1979,1980)$. Birth weights were recorded for all neonatal calves as part of the standard operating procedures at the USMARC, and the influence of birth weight on ovarian weight and antral follicle counts was investigated in neonatal calves ( $<31 \mathrm{~d}$ of age). Pairs of ovaries from neonatal calves were used for this portion of the analysis because the neonatal calves represented the least truncated set of data with no culling due to reproductive performance. Furthermore, this was an age before the initiation of follicular waves and estrous cycles, and there was no issue of follicular waves influencing the interpretation of the data.

\section{Exp. 3}

Crossbred beef heifers ( $\mathrm{n}=406 ; 353$ to $463 \mathrm{~d}$ of age) at 3 locations ( 2 pole sheds at USMARC and 1 pole shed at Mead, NE) were subjected to ovarian ultrasonography on unknown day of the estrous cycle. Each ovary within a heifer was scanned using an Aloka-500 linear array transrectal probe $(7.5-\mathrm{MHz}$ transducer, Aloka Ultrasound, Wallingford, CT). All small (3 to $5 \mathrm{~mm}$ ), medium (6 to $10 \mathrm{~mm})$, and large $(>10 \mathrm{~mm})$ follicles, and CL were counted by a single technician at the time of ultrasonography. At 1 location (Mead, NE), heifers also were evaluated for a reproductive tract score according to the methods reported in Martin et al. (1992), and ovarian length and height were measured. Stage of the estrous cycle was estimated using a modification of the method of Ireland et al. $(1979,1980)$ adapted for use with ultrasonography. Briefly, the presence or absence of luteal tissue detectable by ultrasonography, and the selection of medium and large follicles was used to classify the stage of the estrous cycles. The stages were defined as $1=$ no luteal tissue detectable by ultrasonography; $2=$ luteal tissue detectable by ultrasonography and only small ( 3 to $5 \mathrm{~mm}$ ) follicles; $3=$ luteal tissue detectable by ultrasonography and medium (6 to 10 
Table 1. Influence of stage of the estrous cycle on ovarian morphology in ovaries collected at the abattoir (Exp. 1)

\begin{tabular}{|c|c|c|c|c|}
\hline Item & $\mathrm{n}^{1}$ & $\mathrm{AFC}^{2}$ & Total ovarian wt, $\mathrm{g}$ & $\mathrm{CL}^{3}$ wt, $\mathrm{g}$ \\
\hline \multicolumn{5}{|c|}{ Stage of the estrous cycle ${ }^{4}$} \\
\hline Stage 1 & 5 & $20.4 \pm 6.8$ & $11.9 \pm 1.6$ & $1.4 \pm 0.8^{\mathrm{a}}$ \\
\hline Stage 2 & 32 & $33.1 \pm 2.7$ & $13.1 \pm 0.6$ & $5.5 \pm 0.3^{\mathrm{b}}$ \\
\hline Stage 3 & 30 & $32.9 \pm 2.8$ & $13.8 \pm 0.7$ & $5.6 \pm 0.3^{\mathrm{b}}$ \\
\hline Stage 4 & 5 & $28.2 \pm 6.8$ & $15.8 \pm 1.6$ & $1.9 \pm 0.8^{\mathrm{a}}$ \\
\hline \multicolumn{5}{|c|}{ Stage of the wave } \\
\hline Early-wave & 13 & $34.1 \pm 4.3$ & $13.6 \pm 1.0$ & $5.3 \pm 0.6$ \\
\hline Mid-wave & 8 & $35.4 \pm 5.5$ & $14.1 \pm 1.3$ & $3.4 \pm 0.8$ \\
\hline Late-wave & 51 & $30.7 \pm 2.2$ & $13.4 \pm 0.5$ & $5.2 \pm 0.3$ \\
\hline
\end{tabular}

mm) follicles; and $4=$ luteal tissue detectable by ultrasonography and large follicles $(>10 \mathrm{~mm})$.

At the 2 USMARC locations, heifers were pasture mated with bulls for a 60-d breeding season, and pregnancy was determined by ultrasonography $65 \mathrm{~d}$ after removal of the bulls. At Mead, heifers were synchronized with 2 injections of $\mathrm{PGF}_{2 \alpha}$ (25 $\mathrm{mg}$ of Lutalyse, i.m.; Pfizer Animal Health) $11 \mathrm{~d}$ apart and artificially inseminated by a single technician $12 \mathrm{~h}$ after detection of standing estrus. Approximately 10 to $11 \mathrm{~d}$ after the first AI, heifers were placed with bulls for an additional $60 \mathrm{~d}$. At 50 and $100 \mathrm{~d}$ after the removal of the bulls, heifers were subjected to ultrasonography to determine pregnancy status.

\section{Statistical Analyses}

In Exp. 1, differences between low and high AFC ovarian pairs were analyzed using the GLM Procedure (SAS Inst. Inc., Cary, NC) with stage of the estrous cycle or stage of the wave and group (low or high AFC) as independent variables.

For Exp. 2, the relationship between individual ovarian morphology and individual birth weight for all calves $<31$ d of age $(n=181)$ were analyzed within each heifer using the REG procedure of SAS. Descriptive statistics of neonatal calves for left follicle count, right follicle count, AFC (defined as the sum of left follicle count and right follicle count), left ovarian weight, right ovarian weight, total ovarian weight (TOW; defined as the sum of left ovarian weight and right ovarian weight), birth weight, and age were computed with the MEANS procedure of SAS. For neonatal calves and mature cows, linear and quadratic relationships between ovarian morphology within an animal and age corrected for stage of the estrous cycle (where applicable) were analyzed using the REG procedure of SAS.

In Exp. 3, differences in birth weight of heifers and their individual ovarian morphological data between low and high AFC were analyzed using the GLM pro- cedure of SAS with stage of the estrous cycle, population, and group (low AFC or high AFC) as independent variables. In this model, the population code accounts for variation due to differences in location and management. Fertility data were analyzed by logistic regression using the GENMOD procedure of SAS with a binomial distribution and a logistic link. Independent variables were population, stage of the estrous cycle, and group (low AFC or high AFC).

\section{RESULTS}

\section{Exp. 1}

As was expected based on the classification system, luteal weight was less during stage 1 and stage 4 than during the luteal phase (stage 2 and 3 ) in Exp. 1 (Table $1)$. Neither stage of the estrous cycle $(P=0.70)$ nor stage of the wave $(P=0.62)$ influenced AFC in Exp. 1. Total ovarian weight, excluding CL weight, did not differ between the 4 stages of the estrous cycle or the 3 stages of follicular development. The comparison of ovarian pairs with low and high AFC demonstrated the expected difference in AFC (low $=6.9 \pm 8.1$ vs. high $=37.4 \pm 3.1$ antral follicles; $P=0.0003$ ), but no difference in average ovarian weight (low $=6.4 \pm 1.0$ vs. high $=7.0 \pm 0.4 \mathrm{~g} ; P=0.51$ ).

\section{Exp. 2}

Neonatal bovine ovaries varied greatly in appearance (Figure 1) and ranged from an absence of any visible antral follicles to a maximum of 63 visible antral follicles in the paired ovaries. The means \pm SEM and the range for the examined phenotypes are presented in Table 2. There was no influence of age on the ovarian morphology examined in neonatal heifers $<31 \mathrm{~d}$ of age. Birth weight had a small but positive influence on AFC, such that total follicle number in the ovarian cortex increased as birth weight increased $(P=0.007$; 
A.

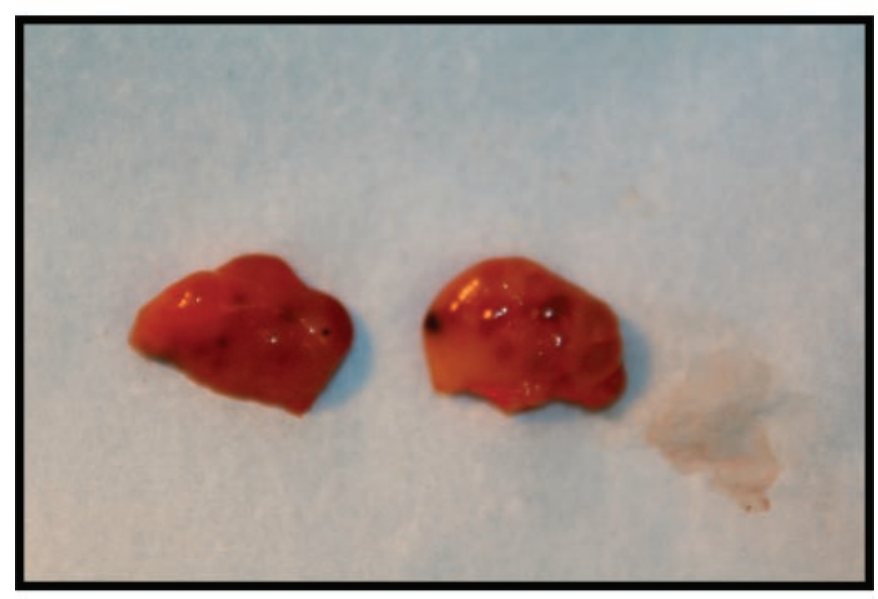

B.

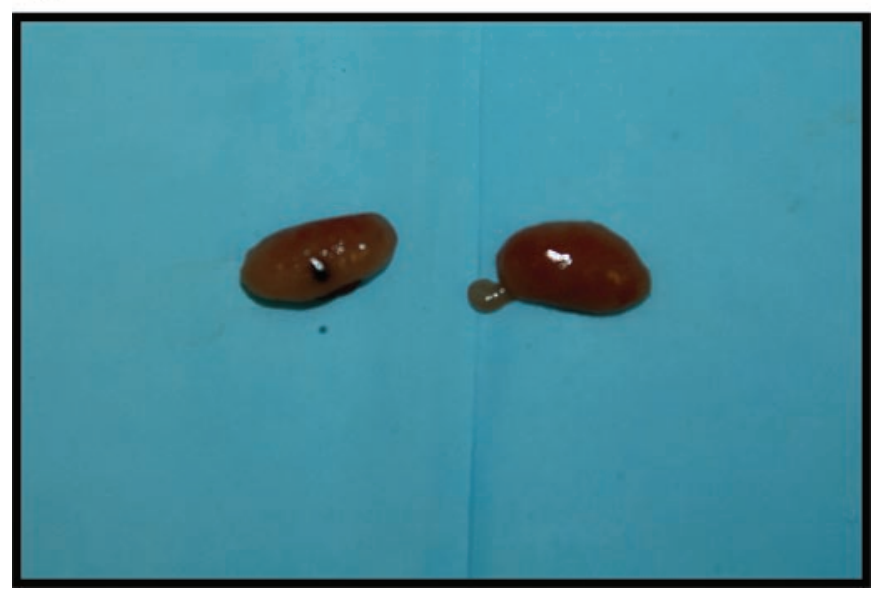

Figure 1. Ovaries from heifer calves on the day of birth. There was significant variation in the numbers of visible antral follicles between heifers. (A) A pair of ovaries weighing $0.7 \mathrm{~g} /$ ovary with many visible antral follicles, (B) a pair of ovaries weighing $0.2 \mathrm{~g}$ /ovary with only 1 visible antral follicle.

Figure 2). An increase in birth weight also resulted in a modest increase in TOW $(P=0.03$; Figure 3$)$.

There was a quadratic effect of age on AFC within the bovine ovary $(P<0.0001$; Figure 4$)$ such that AFC increased until about 5 yr of age and decreased thereafter. Similarly, there was a quadratic effect of age on TOW $(P<0.0001$; Figure 5$)$.

Within a cow, there was a positive relationship in ovarian phenotypes; as the number of follicles in the left ovary increased, the number of follicles in the right ovary increased $(P<0.0001$; Figure 6$)$. The weights of the 2 ovaries were also positively related $(P<0.0001$; Figure 7).

\section{Exp. 3}

The distribution of AFC for crossbred beef heifers is provided in Table 3. Using the methods of Ireland et al. (2008), $21.2 \%$ of the heifers were classified as low AFC, whereas $44.6 \%$ of the heifers were classified as high AFC. There was no effect $(P=0.36)$ of stage of the estrous cycle on the number of antral follicles detectable by ultrasonography. Antral follicle count ranged from $23.5 \pm 0.7$ to $25.5 \pm 1.2$ across the 4 stages of the estrous cycle.

As expected, high AFC heifers had a greater number of follicles than low AFC heifers (low $=11.7 \pm 0.26$ vs. high $=34.2 \pm 0.54$ antral follicles; $P<0.0001$; Table 4 ). The length of the ovary was also greater in high AFC heifers as compared with low AFC heifers $(P=0.001)$, and there was a tendency $(P=0.07)$ for the height of the ovary to be greater in the high AFC heifers. There was no difference in age or reproductive tract score between low and high AFC heifers. The low AFC heifers were lighter at birth by about $3 \mathrm{~kg}(P=0.003)$, and a smaller $(P=0.05)$ percentage of the low AFC heifers was pregnant at the end of the breeding season. There was a strong positive correlation $(\mathrm{r}=0.95 ; P<0.0001)$ between the left and right follicle counts within a heifer. However, the presence of large $(>10 \mathrm{~mm})$ follicles did not influence the $\operatorname{AFC}(P=0.57)$.

\section{DISCUSSION}

Here we report for the first time that ultrasonography can be used to assess follicle numbers in beef cows at random stages of the estrous cycle with no effects of large follicles, and that AFC could be a potential indicator of heifer pregnancy rates because low AFC heifers had decreased fertility. We can conclude that estimated stage of the estrous cycle had no influence on AFC because of the striking phenotypic similarity between our low and high AFC heifers and those reported by Ireland et al. (2008). It is well-documented that the dominant follicle produces factors that inhibit

Table 2. Means and variation of ovarian phenotypes in neonatal crossbred beef heifers $(<31 \mathrm{~d})$ collected at necropsy (Exp. 2)

\begin{tabular}{|c|c|c|c|c|c|}
\hline Phenotype & $\mathrm{n}^{1}$ & Minimum & Maximum & Median & Mean \pm SEM \\
\hline Left follicle count & 181 & 0 & 35 & 3.0 & $5.0 \pm 0.4$ \\
\hline Right follicle count & 181 & 0 & 28 & 3.0 & $4.8 \pm 0.4$ \\
\hline Antral follicle count & 181 & 0 & 63 & 7.0 & $9.8 \pm 0.8$ \\
\hline Left ovarian weight, $\mathrm{g}$ & 181 & 0.1 & 6.1 & 0.3 & $0.5 \pm 0.1$ \\
\hline Right ovarian weight, $\mathrm{g}$ & 181 & 0.1 & 5.3 & 0.3 & $0.5 \pm 0.1$ \\
\hline Birth weight, $\mathrm{kg}$ & 181 & 16.4 & 63.6 & 34.5 & $34.9 \pm 0.7$ \\
\hline Age, d & 181 & 0 & 30.0 & 0 & $2.1 \pm 0.4$ \\
\hline
\end{tabular}

${ }^{1}$ Number of pairs of ovaries. 


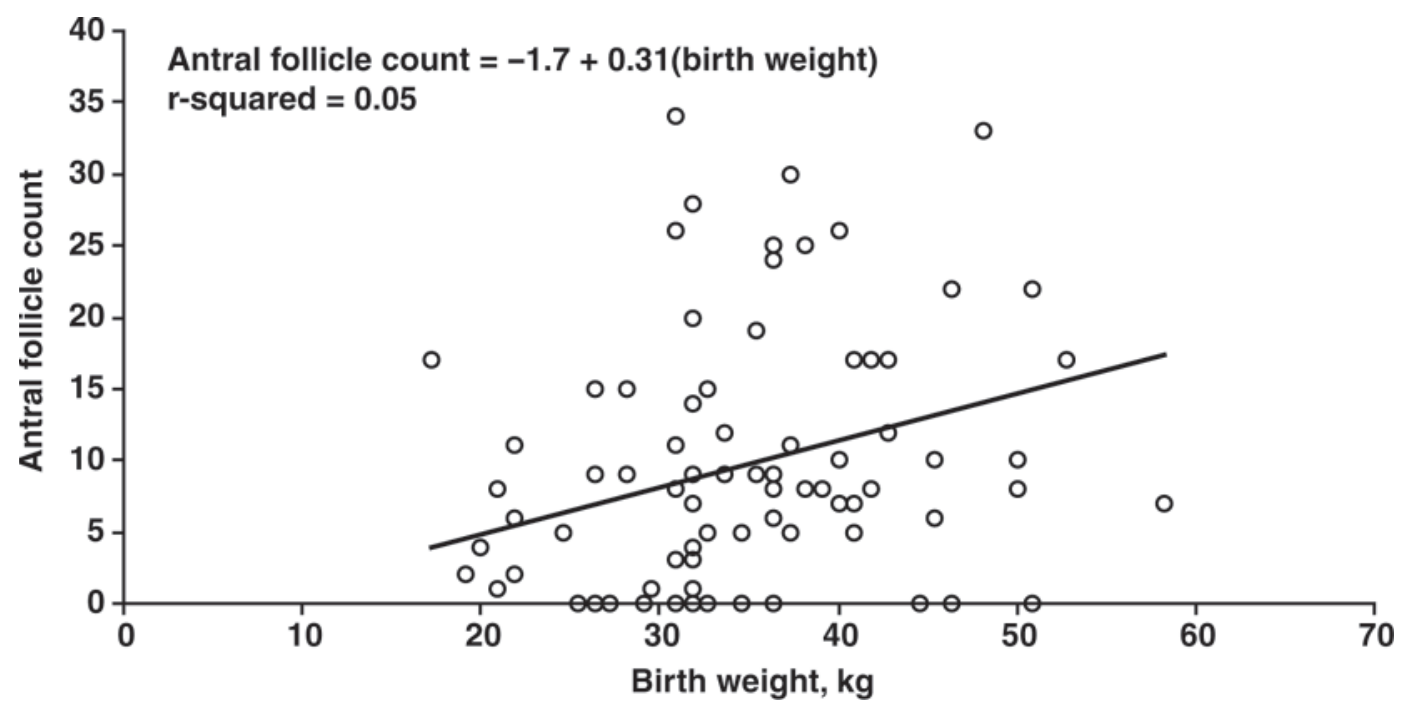

Figure 2. Regression of antral follicle counts on birth weight. As birth weight increased, the number of visible antral follicles in the combined ovaries increased linearly $(P=0.007)$.

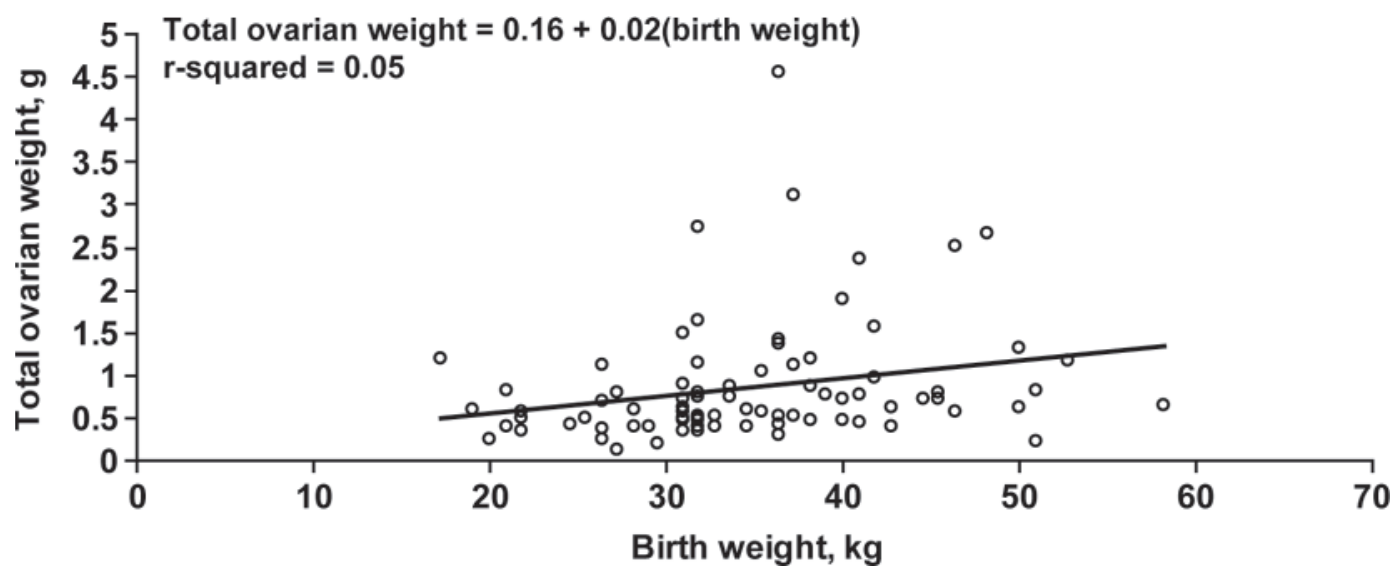

Figure 3. Regression of total ovarian weight on birth weight. As birth weight increased, the weight of the combined ovaries increased linearly $(P=0.03)$.

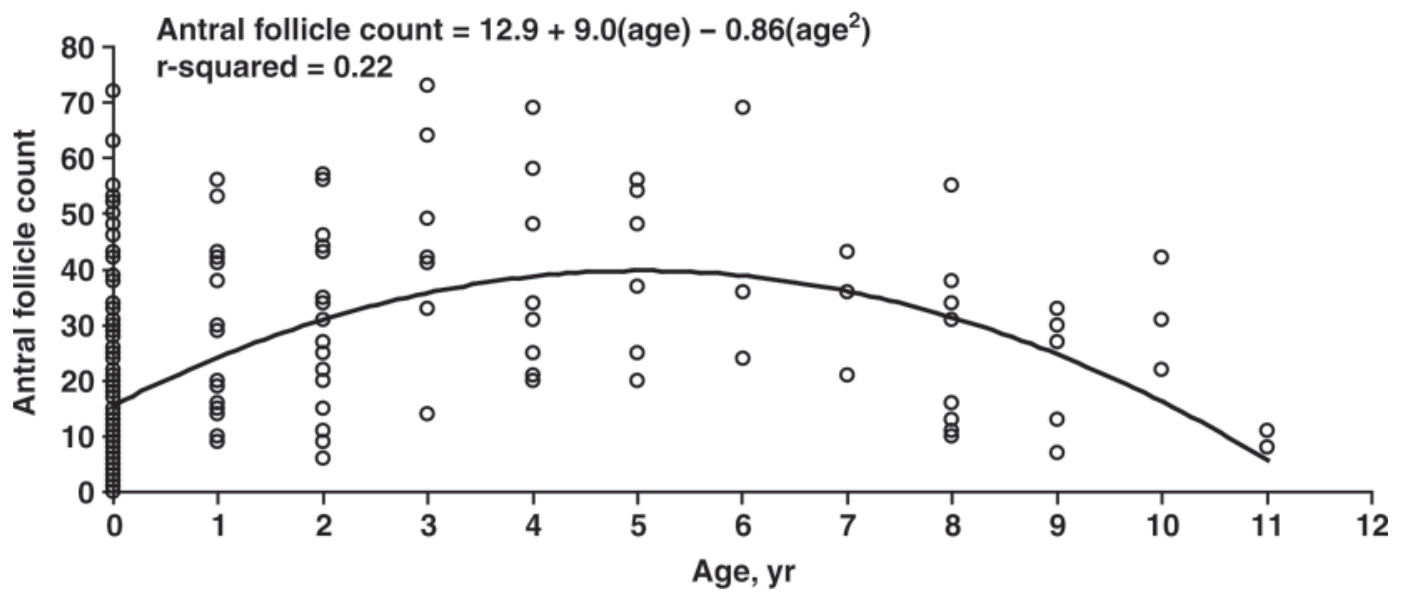

Figure 4. Regression of antral follicle counts on age. As age increased, there was a quadratic effect on the number of antral follicles visible in the ovary $(P<0.0001)$ such that follicle number increased until $5 \mathrm{yr}$ of age and decreased thereafter. 


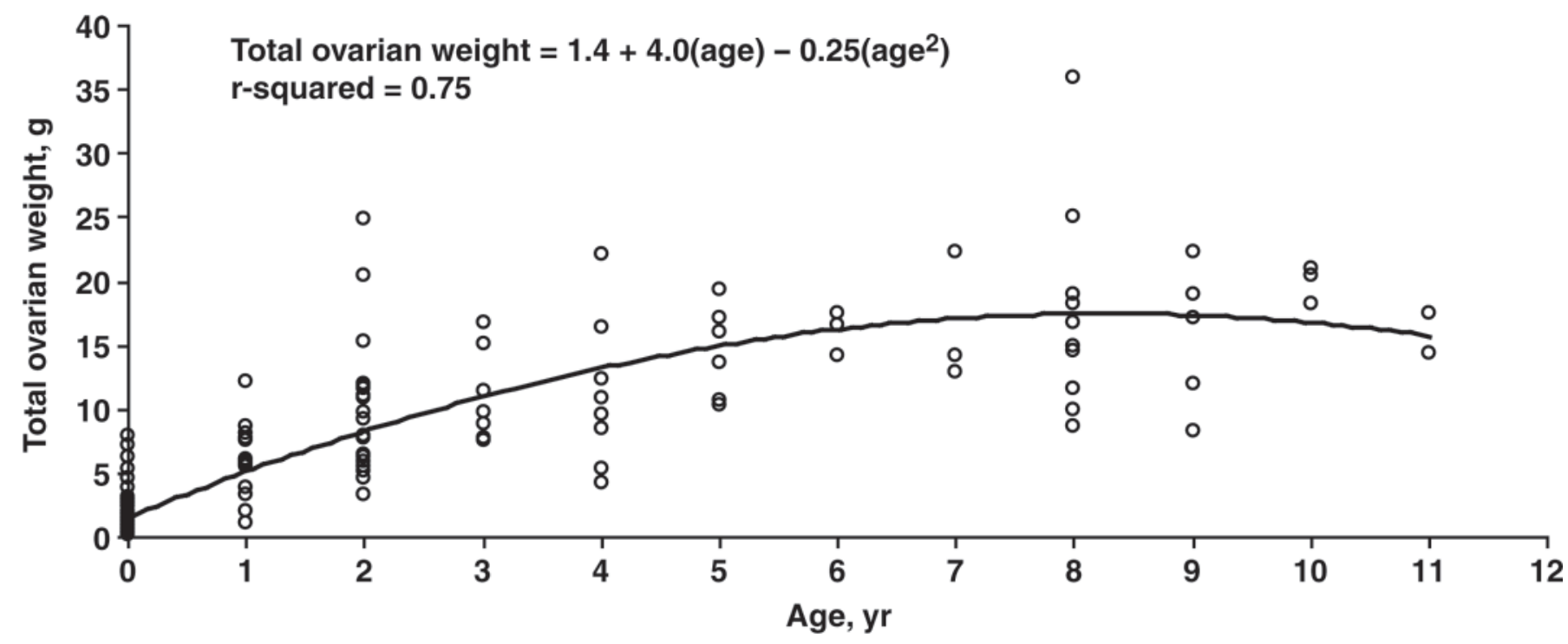

Figure 5. Regression of total ovarian weight on age. As age increased, there was a quadratic effect on the total ovarian weight $(P<0.0001)$.

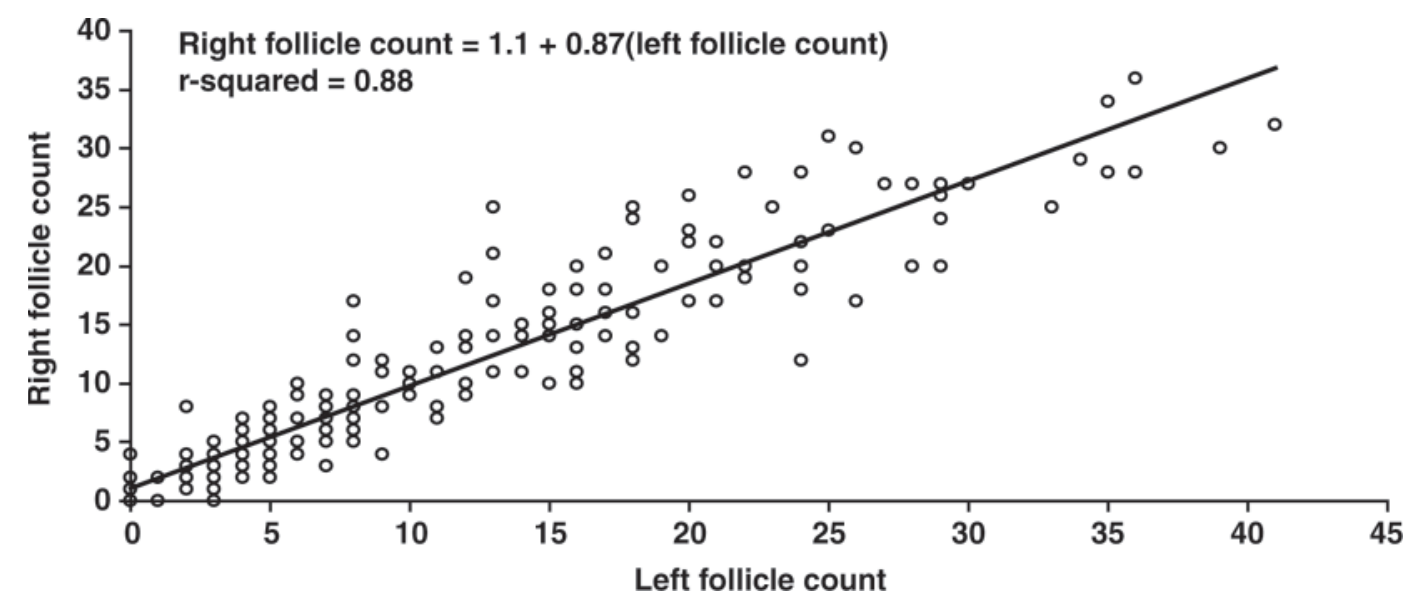

Figure 6. Regression of right follicle count on left follicle count. As the number of follicles in the right ovary increased, the number of follicles in the left ovary increased linearly $(P<0.0001)$.

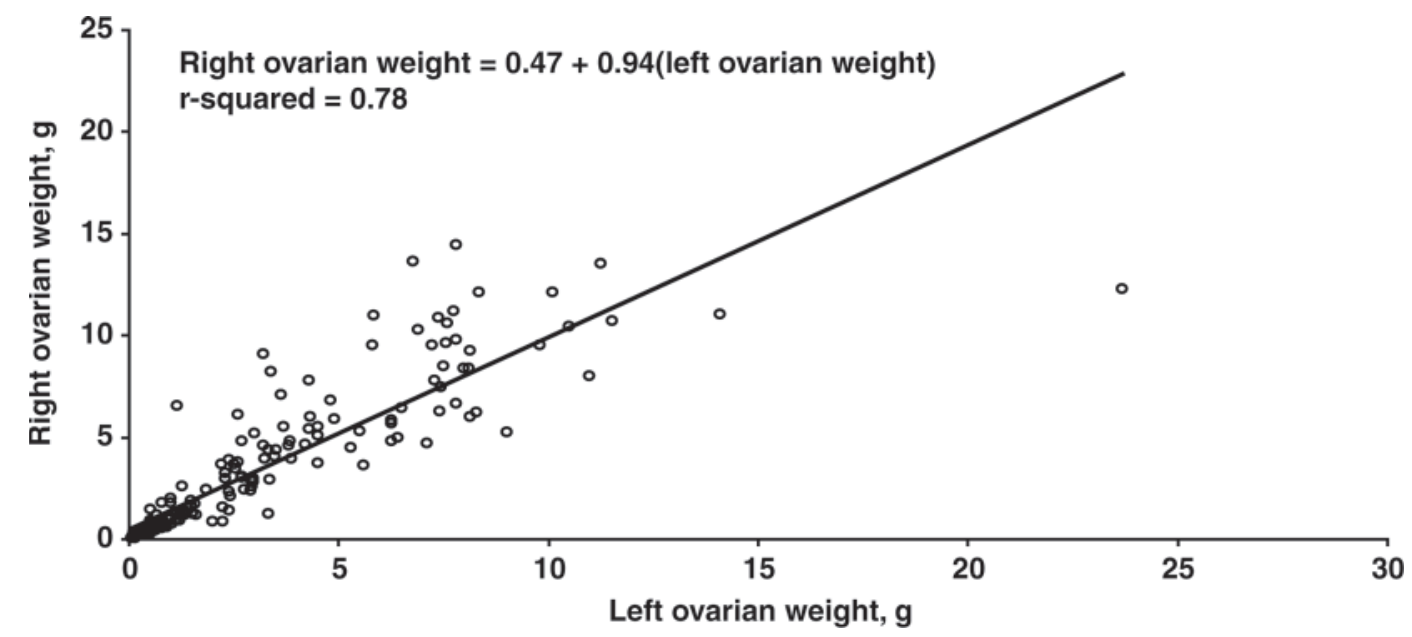

Figure 7. Regression of right ovarian weight on left ovarian weight. As the weight of 1 ovary increased, the weight of the contra-lateral ovary increased linearly $(P<0.0001)$. 
the growth of subordinate follicles (Cushman et al., 2005); however, there was no effect of the presence of 1 or more large follicles on the number of small follicles in the current study. Although this method does not allow the clear diagnosis of whether these large follicles are growing or regressing, it does indicate that this is of minimal consequence for using ultrasonography to assess the numbers of follicles in beef heifers where day of the estrous cycle will most often not be known. The identification of medium and large follicles while counting $\mathrm{AFC}$ adds very little time to the process, and these data can be used to estimate stage of the estrous cycle for modeling purposes.

Whereas stage of the estrous cycle was not significant in any models used in the present study, we chose to keep it in all models because Ireland et al. (1979) reported a modest increase in total follicle number in stage 4 (d 18 to 20 of estrous cycle). This should account for random effects of stage of the estrous cycle on AFC. Furthermore, as we gather data on larger numbers of heifers for genetic analysis, the random influence of stage of the estrous cycle becomes minimal.

In the present study, we demonstrated a small but positive relationship between TOW at birth, the number of antral follicles in the ovarian cortex at birth, and birth weight. We reported previously that selecting cows for increased ovulation rate resulted in an increase in the size of the ovarian reserve (Cushman et al., 2000; Echternkamp et al., 2004). In the USMARC Twinner population (Gregory et al., 1997), birth weight and mature BW had a positive genetic correlation with ovulation rate, indicating a link between $\mathrm{BW}$ and ovarian function. However, we identified no association between a polymorphism in the SPP1 (osteopontin) gene and ovulation rate in cows from the Twinner population, although this polymorphism was shown to associate with BW in several USMARC cattle populations (Allan et al., 2007; White et al., 2007). Osteopontin is located on BTA6, and to date, no QTL for ovulation rate has been identified on BTA6 for the Twinner population (Kappes et al., 2000). The association between BW and the size of the ovarian reserve is supported by a recent report linking the Booroola genotype positively to BW in sheep (Guan et al., 2007). However, like SPP1, bone morphogenetic protein receptor-1B, which carries the Booroola polymorphism, was located on BTA6 (Kim et al., 2003).

This relationship between birth weight and the ovarian reserve has been documented for ewe lambs (Da Silva et al., 2002, 2003); however, our trial is the first to demonstrate a relationship between birth weight and AFC in beef heifers. Girls born small for gestational age had smaller ovaries, fewer antral follicles, and decreased ovulation rate (Ibanez et al., 2000; Ibanez and de Zegher, 2006). Thus, nutritional status of the dam during pregnancy and its influence on birth weight could have dramatic implications for the reproductive capacity of her female offspring. A recent study reported a genetic correlation of 0.15 between BW at $550 \mathrm{~d}$ of age and
Table 3. Distribution of antral follicle count (AFC) detectable by ultrasonography among crossbred beef heifers (353 to 463 d of age, Exp. 3)

\begin{tabular}{|c|c|c|c|}
\hline $\mathrm{AFC}$ & Frequency & Percentage & $\begin{array}{l}\text { Cumulative } \\
\text { percentage }\end{array}$ \\
\hline 4 & 1 & 0.25 & 0.25 \\
\hline 7 & 2 & 0.49 & 0.74 \\
\hline 8 & 6 & 1.48 & 2.22 \\
\hline 9 & 7 & 1.72 & 3.94 \\
\hline 10 & 13 & 3.20 & 7.14 \\
\hline 11 & 8 & 1.97 & 9.11 \\
\hline 12 & 14 & 3.45 & 12.56 \\
\hline 13 & 8 & 1.97 & 14.53 \\
\hline 14 & 15 & 3.69 & 18.53 \\
\hline 15 & 12 & 2.96 & 21.18 \\
\hline 16 & 24 & 5.91 & 27.09 \\
\hline 17 & 11 & 2.71 & 29.8 \\
\hline 18 & 20 & 4.93 & 34.73 \\
\hline 19 & 18 & 4.43 & 39.16 \\
\hline 20 & 13 & 3.20 & 42.36 \\
\hline 21 & 19 & 4.68 & 47.04 \\
\hline 22 & 12 & 2.96 & 50.00 \\
\hline 23 & 12 & 2.96 & 52.96 \\
\hline 24 & 10 & 2.46 & 55.42 \\
\hline 25 & 18 & 4.43 & 59.85 \\
\hline 26 & 10 & 2.46 & 62.32 \\
\hline 27 & 6 & 1.48 & 63.79 \\
\hline 28 & 10 & 2.46 & 66.26 \\
\hline 29 & 15 & 3.69 & 69.95 \\
\hline 30 & 10 & 2.46 & 72.41 \\
\hline 31 & 10 & 2.46 & 74.88 \\
\hline 32 & 12 & 2.96 & 77.83 \\
\hline 33 & 6 & 1.48 & 79.31 \\
\hline 34 & 11 & 2.71 & 82.02 \\
\hline 35 & 7 & 1.72 & 83.74 \\
\hline 36 & 4 & 0.99 & 84.73 \\
\hline 37 & 8 & 1.97 & 86.70 \\
\hline 38 & 5 & 1.23 & 87.93 \\
\hline 39 & 8 & 1.97 & 89.90 \\
\hline 40 & 7 & 1.72 & 91.63 \\
\hline 41 & 5 & 1.23 & 92.86 \\
\hline 42 & 7 & 1.72 & 94.58 \\
\hline 43 & 4 & 0.99 & 95.57 \\
\hline 44 & 4 & 0.99 & 96.55 \\
\hline 45 & 1 & 0.25 & 96.80 \\
\hline 46 & 1 & 0.25 & 97.04 \\
\hline 47 & 1 & 0.25 & 97.29 \\
\hline 48 & 3 & 0.74 & 98.03 \\
\hline 49 & 1 & 0.25 & 98.28 \\
\hline 50 & 2 & 0.49 & 98.77 \\
\hline 52 & 1 & 0.25 & 99.01 \\
\hline 53 & 1 & 0.25 & 99.26 \\
\hline 55 & 2 & 0.49 & 99.75 \\
\hline 56 & 1 & 0.28 & 100.00 \\
\hline
\end{tabular}

stayability in Nelore cows (Silva et al., 2006), further supporting a positive link between BW and cow productivity.

We reported a positive relationship between AFC and TOW. In Booroola sheep during early ovarian development, when there were no antral follicles present, ovarian weights and cortical volumes were greater and the pool of primordial follicles was larger compared with ewe lambs that did not carry the Booroola mutation (Smith et al., 1994). The ovarian cortex is needed to 
Table 4. Average antral follicle count (AFC), ovary size, reproductive tract score, birth weight, age, and pregnancy rate in heifers with low ( $\leq 15$ follicles) and high $(\geq 25$ follicles) AFC (Exp. 3)

\begin{tabular}{lccc}
\hline \hline Item & Low AFC, $\mathrm{n}$ & High AFC, $\mathrm{n}$ & $P$-value \\
\hline Ovary height, $^{1} \mathrm{~mm}$ & $12.4 \pm 0.18(14)$ & $14.3 \pm 0.04(41)$ & 0.07 \\
Ovary length, $^{2} \mathrm{~mm}$ & $22.0 \pm 0.13(14)$ & $26.6 \pm 0.05(41)$ & 0.001 \\
RTS $^{3}$ & $4.1 \pm 0.29(14)$ & $4.5 \pm 0.08(44)$ & 0.13 \\
Birth weight, $\mathrm{kg}$ & $35.8 \pm 0.57(84)$ & $38.7 \pm 0.38(178)$ & 0.003 \\
Age, d & $406.9 \pm 1.55(84)$ & $408.2 \pm 1.30(178)$ & 0.59 \\
Percentage pregnant & $85.5 \pm 3.4(84)$ & $94.3 \pm 2.3(178)$ & 0.05 \\
\hline
\end{tabular}

${ }^{1}$ Average height of the 2 ovaries within a heifer.

${ }^{2}$ Average length of the 2 ovaries within a heifer.

${ }^{3} \mathrm{RTS}=$ reproductive tract score (Martin et al., 1992).

support primordial follicle activation and growth in culture (Wandji et al., 1996; Cushman et al., 2002, 2007), indicating that the ovarian cortex provides crucial support for the early stages of follicle development in the cow. Therefore, it is logical that a greater ovarian cortical mass is required to support the growth of a larger number of follicles and that this would translate into a greater ovarian mass.

Although we did not investigate the relationship between AFC and the number of microscopic follicles in the ovarian reserve in the present study, previous studies have shown that these relationships are positive in cows (Erickson, 1966; Cushman et al., 1999, 2000; Ireland et al., 2008) and in women (Scheffer et al., 1999). Because removal of the ovaries from a breeding female for histological examination is not feasible, the use of ultrasonography to count antral follicles has greater potential for tracking the ovarian reserve of a cow across her reproductive lifetime in a production setting and for understanding how follicle numbers influence fertility, stayability, and productivity. The use of slaughter house and necropsy ovaries in the present study helped to validate the data collected by ultrasonography and to identify factors of potential importance as the heifers on the ultrasonography study proceed through their reproductive life.

The large variation among cows in the weights of the ovaries and the number of antral follicles was in agreement with previously published results from morphological (Erickson, 1966; Cushman et al., 1999; Taneja et al., 2000; Murasawa et al., 2005) and ultrasonographic (Burns et al., 2005; Ireland et al., 2007) examination of bovine ovaries. Although there was large variation in numbers of follicles between cows, there was very little difference in the number of follicles in the left and right ovary within a cow. The strong positive relationship between the number of antral follicles in 1 ovary and the number of antral follicles in the contralateral ovary is in agreement with previous work by Erickson (1966) and indicates that an ultrasonographic scan of 1 ovary may be as useful as an ultrasonographic scan of both ovaries in predicting size of the ovarian reserve. This could decrease the labor involved by decreasing the individual cow time when ultrasonography is being used to assess the AFC of a cow in a production setting because only 1 ovary would need to be subjected to an ultrasonographic scan.

We observed a decline in the number of antral follicles beginning at about $5 \mathrm{yr}$ of age. This is the age when Erickson (1966) began to observe a decrease in the number of primordial follicles. Some effects of age on AFC and fertility have already been examined in cows. Older Hereford cows have fewer follicle numbers detectable by ultrasonography (Malhi et al., 2005, 2006) and decreased oocyte competence (Malhi et al., 2007) when compared with their younger daughters; however, these older Hereford cows were of an extreme age (13to 14-yr-old). Starbuck-Clemmer et al. (2007) reported fewer antral follicles detectable by ultrasound in mature Angus cows than Angus heifers. Renquist et al. (2006) reported that pregnancy rate in mature Angus cows peaked at $6 \mathrm{yr}$ of age and decreased thereafter. Similarly, pregnancy rates began to decline in cattle selected for increased fecundity at about 5 to 6 yr of age (Echternkamp et al., 2007), and Erickson et al. (1976) reported a cumulative frequency of infertility, defined as failing to produce a calf in 2 consecutive years, of $15 \%$ at 6 yr of age. Therefore, the age-related decline in the ovarian reserve and fertility in the beef cow may begin earlier than previously believed.

In conclusion, we have demonstrated that counting the number of antral follicles at random stage of the estrous cycle in beef cows has minimal influence on total follicle numbers and that low AFC was associated with a decreased heifer pregnancy rate. We also reported a small but positive relationship between birth weight, ovarian weight, and AFC in neonatal heifers that lasts to reproductive maturity. Although there are, clearly, other factors that influence variation in the size of the ovaries and the number of antral follicles at birth, this positive relationship between birth weight, ovarian weight, and the number of antral follicles in the ovaries cannot be ignored. Finally, we demonstrated a quadratic effect of age on AFC in beef cows, indicating that AFC increase until about 5 yr of age and begin to decline thereafter in the bovine ovary. Ultrasonography studies with repeated measurements during the reproductive life of a cow will be necessary to confirm these 
results and to relate AFC to fertility and stayability in beef cows.

\section{LITERATURE CITED}

Allan, M. F., R. M. Thallman, R. A. Cushman, S. E. Echternkamp, S. N. White, L. A. Kuehn, E. Casas, and T. P. Smith. 2007. Association of a single nucleotide polymorphism in SPP1 with growth traits and twinning in a cattle population selected for twinning rate. J. Anim. Sci. 85:341-347.

Alvarez, P., L. J. Spicer, C. C. Chase Jr., M. E. Payton, T. D. Hamilton, R. E. Stewart, A. C. Hammond, T. A. Olson, and R. P. Wettemann. 2000. Ovarian and endocrine characteristics during an estrous cycle in Angus, Brahman, and Senepol cows in a subtropical environment. J. Anim. Sci. 78:1291-1302.

Broekmans, F. J., E. A. Knauff, E. R. te Velde, N. S. Macklon, and B. C. Fauser. 2007. Female reproductive ageing: Current knowledge and future trends. Trends Endocrinol. Metab. 18:58-65.

Burns, D. S., F. Jimenez-Krassel, J. L. Ireland, P. G. Knight, and J. J. Ireland. 2005. Numbers of antral follicles during follicular waves in cattle: Evidence for high variation among animals, very high repeatability in individuals, and an inverse association with serum follicle-stimulating hormone concentrations. Biol. Reprod. 73:54-62.

Cushman, R. A., M. F. Allan, S. A. Jones, G. P. Rupp, and S. E. Echternkamp. 2007. Localization of Period $1 \mathrm{mRNA}$ in the ruminant oocyte and investigations of its role in ovarian function. Anim. Reprod. Sci. 99:93-105.

Cushman, R. A., M. F. Allan, G. D. Snowder, R. M. Thallman, and S. E. Echternkamp. 2005. Evaluation of ovulation rate and ovarian phenotype in puberal heifers from a cattle population selected for increased ovulation rate. J. Anim. Sci. 83:18391844.

Cushman, R. A., J. C. DeSouza, V. S. Hedgpeth, and J. H. Britt. 1999. Superovulatory response of one ovary is related to the micro- and macroscopic population of follicles in the contralateral ovary of the cow. Biol. Reprod. 60:349-354.

Cushman, R. A., V. S. Hedgpeth, S. E. Echternkamp, and J. H. Britt. 2000. Evaluation of numbers of microscopic and macroscopic follicles in cattle selected for twinning. J. Anim. Sci. 78:1564-1567.

Cushman, R. A., C. M. Wahl, and J. E. Fortune. 2002. Bovine ovarian cortical pieces grafted to chick embryonic membranes: A model for studies on the activation of primordial follicles. Hum. Reprod. 17:48-54.

Da Silva, P., R. P. Aitken, S. M. Rhind, P. A. Racey, and J. M. Wallace. 2002. Impact of maternal nutrition during pregnancy on pituitary gonadotrophin gene expression and ovarian development in growth-restricted and normally grown late gestation sheep fetuses. Reproduction 123:769-777.

Da Silva, P., R. P. Aitken, S. M. Rhind, P. A. Racey, and J. M. Wallace. 2003. Effect of maternal overnutrition during pregnancy on pituitary gonadotrophin gene expression and gonadal morphology in female and male foetal sheep at day 103 of gestation. Placenta 24:248-257.

Echternkamp, S. E., R. A. Cushman, M. F. Allan, R. M. Thallman, and K. E. Gregory. 2007. Effects of ovulation rate and fetal number on fertility in twin-producing cattle. J. Anim. Sci. 85:3228-3238

Echternkamp, S. E., A. J. Roberts, D. D. Lunstra, T. Wise, and L. J. Spicer. 2004. Ovarian follicular development in cattle selected for twin ovulations and births. J. Anim. Sci. 82:459-471.

Erickson, B. H. 1966. Development and senescence of the postnatal bovine ovary. J. Anim. Sci. 25:800-805.

Erickson, B. H., R. A. Reynolds, and R. L. Murphree. 1976. Ovarian characteristics and reproductive performance of the aged cow. Biol. Reprod. 15:555-560.

Gregory, K. E., G. L. Bennett, L. D. Van Vleck, S. E. Echternkamp, and L. V. Cundiff. 1997. Genetic and environmental parameters for ovulation rate, twinning rate, and weight traits in a cattle population selected for twinning. J. Anim. Sci. 75:1213-1222.

Guan, F., S. R. Liu, G. Q. Shi, and L. G. Yang. 2007. Polymorphism of Fecb gene in nine sheep breeds or strains and its effects on litter size, lamb growth and development. Anim. Reprod. Sci. 99:44-52.

Ibanez, L., and F. de Zegher. 2006. Puberty and prenatal growth. Mol. Cell. Endocrinol. 254-255:22-25.

Ibanez, L., N. Potau, G. Enriquez, and F. de Zegher. 2000. Reduced uterine and ovarian size in adolescent girls born small for gestational age. Pediatr. Res. 47:575-577.

Ireland, J. J., P. B. Coulson, and R. L. Murphree. 1979. Follicular development during four stages of the estrous cycle in beef cattle. J. Anim. Sci. 49:1261-1269.

Ireland, J. J., R. L. Murphee, and P. B. Coulson. 1980. Accuracy of predicting stages of bovine estrous cycle by gross appearance of the corpus luteum. J. Dairy Sci. 63:155-160.

Ireland, J. J., F. Ward, F. Jimenez-Krassel, J. L. H. Ireland, G. W. Smith, P. Lonergan, and A. C. O. Evans. 2007. Follicle numbers are highly repeatable within individual animals but are inversely correlated with FSH concentrations and the proportion of good-quality embryos after ovarian stimulation in cattle. Hum. Reprod. 22:1687-1695.

Ireland, J. L., D. Scheetz, F. Jimenez-Krassel, A. P. Themmen, F. Ward, P. Lonergan, G. W. Smith, G. I. Perez, A. C. Evans, and J. J. Ireland. 2008. Antral follicle count reliably predicts number of morphologically healthy oocytes and follicles in ovaries of young adult cattle. Biol. Reprod. 79:1219-1225.

Kappes, S. M., G. L. Bennett, J. W. Keele, S. E. Echternkamp, K. E. Gregory, and R. M. Thallman. 2000. Initial results of genomic scans for ovulation rate in a cattle population selected for increased twinning rate. J. Anim. Sci. 78:3053-3059.

Kim, J. G., T. P. Smith, W. M. Snelling, J. L. Vallet, and R. K. Christenson. 2003. Linkage mapping of the bovine bone morphogenetic protein receptor-1b (BMPr1b) to chromosome 6 . Anim. Genet. 34:311.

Malhi, P. S., G. P. Adams, R. J. Mapletoft, and J. Singh. 2007. Oocyte developmental competence in a bovine model of reproductive aging. Reproduction 134:233-239.

Malhi, P. S., G. P. Adams, R. A. Pierson, and J. Singh. 2006. Bovine model of reproductive aging: Response to ovarian synchronization and superstimulation. Theriogenology 66:1257-1266.

Malhi, P. S., G. P. Adams, and J. Singh. 2005. Bovine model for the study of reproductive aging in women: Follicular, luteal, and endocrine characteristics. Biol. Reprod. 73:45-53.

Martin, L. C., J. S. Brinks, R. M. Bourdon, and L. V. Cundiff. 1992. Genetic effects on beef heifer puberty and subsequent reproduction. J. Anim. Sci. 70:4006-4017.

Martinez, G. E., R. M. Koch, L. V. Cundiff, K. E. Gregory, S. D. Kachman, and L. D. Van Vleck. 2005. Genetic parameters for stayability, stayability at calving, and stayability at weaning to specified ages for Hereford cows. J. Anim. Sci. 83:2033-2042.

Martinez, G. E., R. M. Koch, L. V. Cundiff, K. E. Gregory, and L. D. Van Vleck. 2004a. Genetic parameters for six measures of length of productive life and three measures of lifetime production by 6 yr after first calving for Hereford cows. J. Anim. Sci. 82:1912-1918.

Martinez, G. E., R. M. Koch, L. V. Cundiff, K. E. Gregory, and L. D. Van Vleck. 2004b. Number of calves born, number of calves weaned, and cumulative weaning weight as measures of lifetime production for Hereford cows. J. Anim. Sci. 82:1903-1911.

Maurer, R. R., and S. E. Echternkamp. 1985. Repeat-breeder females in beef cattle: Influences and causes. J. Anim. Sci. 61:624-636.

Murasawa, M., T. Takahashi, H. Nishimoto, S. Yamamoto, S. Hamano, and M. Tetsuka. 2005. Relationship between ovarian weight and follicular population in heifers. J. Reprod. Dev. 51:689-693.

Renquist, B. J., J. W. Oltjen, R. D. Sainz, and C. C. Calvert. 2006. Effects of age on body condition and production parameters of multiparous beef cows. J. Anim. Sci. 84:1890-1895. 
Scheffer, G. J., F. J. M. Broekmans, M. Dorland, J. D. F. Habbema, C. W. N. Looman, and E. R. te Velde. 1999. Antral follicle counts by transvaginal ultrasonography are related to age in women with proven natural fertility. Fertil. Steril. 72:845851.

Silva, J. A. I. V., I. B. Formigoni, J. P. Eler, and J. B. S. Ferraz. 2006. Genetic relationship among stayability, scrotal circumference and post-weaning weight in Nelore cattle. Livest. Sci. 99:51-59.

Smith, P., R. Braw-Tal, K. Corrigan, N. L. Hudson, D. A. Heath, and K. P. McNatty. 1994. Ontogeny of ovarian follicle development in Booroola sheep fetuses that are homozygous carriers or non-carriers of the Fec ${ }^{\mathrm{b}}$ gene. J. Reprod. Fertil. 100:485-490.

Starbuck-Clemmer, M. J., H. Hernandez-Fonseca, N. Ahmad, G. Seidel, and E. K. Inskeep. 2007. Association of fertility with numbers of antral follicles within a follicular wave during the oestrous cycle in beef cattle. Reprod. Domest. Anim. 42:337342 .

Taneja, M., P. E. J. Bols, A. Van de Velde, J.-C. Ju, D. Schreiber, M. W. Tripp, H. Levine, Y. Echelard, J. Riesen, and X. Yang. 2000. Developmental competence of juvenile calf oocytes in vitro and in vivo: Influence of donor animal variation and repeated gonadotropin stimulation. Biol. Reprod. 62:206-213.

Wandji, S.-A., V. Srsen, A. K. Voss, J. J. Eppig, and J. E. Fortune. 1996. Initiation in vitro of growth of bovine primordial follicles. Biol. Reprod. 55:942-948.

White, S. N., E. Casas, M. F. Allan, J. W. Keele, W. M. Snelling, T. L. Wheeler, S. D. Shackelford, M. Koohmaraie, and T. P. Smith. 2007. Evaluation in beef cattle of six deoxyribonucleic acid markers developed for dairy traits reveals an osteopontin polymorphism associated with postweaning growth. J. Anim. Sci. $85: 1-10$ 